\title{
The Measure of Financial Stability and its Impact on Foreign Direct Investment: Evidence from BRIC Nations
}

Received: August 09, 2020

doi: I0.4628I/ijafr.v5i2.797

\author{
Anjala Kalsie $P h D$ \\ Assistant Professor \\ Faculty of Management Studies \\ University of Delhi, India \\ E-mail:kalsieanjala@gmail.com \\ Ms. Jyoti Dhamija \\ Research Scholar \\ Faculty of Management Studies \\ University of Delhi, India \\ E-mail: jyoti.d_phdI6@fms.edu \\ Ashima Arora $P h D$ \\ Assistant Professor \\ Shaheed Sukhdev College of Business Studied \\ University of Delhi, India \\ E-mail: ashima.arora@sscbsdu.ac.in
}

Accepted: August 30, 2020

Online Published: October I2, 2020

\begin{abstract}
The stability of the economy has explicitly become a key objective for fiscal, economic, and monetary policy. It is a broader term described by different aspects of finance and the financial system. One variable cannot be recognized for defining and achieving stability. The purpose of this paper is two-fold, one to construct four measures of financial stability (MFS). The second purpose is to use the four constructed measures of financial stability in two stage least square (TSLS) regression framework to know the impact of MFA on Foreign Direct Investment (inwards) of BRIC for a period from 2000-2017. In case of Brazil, all the four measures of financial stability are significant. In case of Russia, government finances are not appropriately managed. In case of China, the large inflow of FDI is because of government policies as rest of the measures are negative. In case of India, the government measures are not efficient to attract the FDI.The openness of the economy is positively contributing to FDI in all countries except India. Of all the four nations Brazil is on the right path.
\end{abstract}

Keywords: Measure Financial Stability, TSLS, Foreign Direct Investment, BRIC.

JEL Classification Codes: F4, F6, HII, E60.

\section{Introduction}

The science and art of central banking are witnessing a fundamental change post-global financial crisis that was guided by the US and European sovereign debt crisis. Price stability always enjoyed the focused attention of the central bank and policymakers. It was popularly realized through policy rates. In the pre-crisis period, an assumption prevailed amongst the policymakers that financial stability is automatically ensured if price stability and macro-economic stability are effectively managed. For instance, it is clear now that despite stable growth and low inflation, financial imbalances emerged in developed economies leading to the emergence of a financial crisis. Thus, the crisis revealed how costly it could be to ignore financial stability as a key objective of study. With changing time, the cross-border spillovers have increased in size and scope. Thus, in the post-crisis period economies are facing a new trilemma, that of simultaneously managing and balancing sovereign debt sustainability, price stability, and financial 
sustainability. It is recognized that there is a significant role to be played by macro-prudential tools to supplement the existing micro-prudential measures. Macro-prudential measures are those policies or regulations that reduce systemic risks, provide financial stability against external and domestic shocks while ensuring its continuous function effectively (Bank for International Settlements, 2010).

Capital flows are hailed as both friend and foe for developing and emerging economies. This is because if they bring the much-sought foreign capital into an economy to support its growth, they also render vulnerability to the economy by exposing its financial and economic systems to external shocks (Kim \& Singal, 2000). Unsurprisingly, there is an enhanced interest in determining the relationship between financial stability and capital flows owing to their potential impact on macroeconomic stability as emphasized in the recent crisis episodes of past (Erturk, 2005). On one hand, the literature argues that financial liberalization realized through opening of capital accounts and domestic deregulations renders the economy unstable leading to crisis even. Underdeveloped financial institutions and banking systems along with an increase in risk-taking and enhanced competition with evolving liberalization in developing economies are hailed as the factors leading to a crisis in the economy (Daniel $\&$ Jones, 2007). On the other hand, literature also argues that financial openness and greater access to capital leads to stronger and more stable financial systems (Kaminsky \& Schmukler, 2008). Similarly, contrary opinion exists in literature about relationship between economic financial stability and capital flows. For instance, there is a belief that capital flows in the form of debt and equity render volatility to the economy owing to the speculative considerations driving their movement. Alternatively, FDI inflows owing to its characteristic of investments in fixed assets and that too of a long-term nature is considered as stability inducing. Compared to the capital flows via debt and equity, FDI is seen as less susceptible to wide reversals and associated volatility in short term.

Accordingly, the following study explores the relationship between capital flows and financial stability. The study evaluates if the relationship between capital flows and financial stability varies across various underlying economies.

\section{Literature Review}

The frequent occurrences of the financial crises in the past and present tend to indicate at the potentially substantial cost of instability in the financial system. Such disruptions also underline the potential strong inter-linkages between financial systems of different economies. These inter-linkages get validated when the instability in financial system of one country have broad consequences for the macroeconomic performances and financial system's stability of other countries. Against the backdrop of grave concerns worldwide for such potentially substantial and significant macroeconomic costs, it becomes important to identify potential vulnerabilities in the financial system through an efficient framework. Accordingly, this section review varied analytical approaches assessing the vulnerabilities in the system, and reviews different frameworks structured for their measurements.

(Aspachs et al., 2006) in their study made a sincere attempt to define a framework for the measurement of financial fragility. The metric was based on the definition of financial stability which was borrowed from the works of (Tsomocos, 2003), (Tsomocos, 2005) and (Goodhart, Sunirand, \& Tsomocos, 2005). The existence of credit risk i.e., the risk of repayment failure was recognized as the main factor in the analysis of money, financial intermediation, and financial instability. Building a model through measurement based on theory, the paper employed a weighted two-factor model with bank repayment rates (PD) and profitability employed as two factors of significance. The study found that two measures of banking sector fragility, namely PD and annual growth rate of the bank equity index having a significant impact on GDP, representing welfare. Subsequently, the weights of factors (two) were used for producing Index for financial fragility.

Analyzing the financial liberalization implications on economic growth, financial stability, and financial development of 4I African economies for a period of 25 years from 1985 to 2010 (Enowbi \& Kupukile, 20I2) used dynamic models in their study. Specifically, the study examined the effect of financial instability on the economic growth of African economies and the association of financial liberalization and financial development with financial instability. The study discovered that financial liberalization and financial development significant positively impact the financial instability. It further found that financial instability significant negatively impact economic growth which appeared to be more pronounced in pre-financial liberalization period relative to the post-financial liberalization period.

The literature appears to be divided on the topic of the relationship between finance and macroeconomic performance. There exists no refuting the Schumpeterian view that credit is the basic requirement for entrepreneurs in financing their innovations. And credit is facilitated by banks and financial markets, thereby emerging as facilitators of growth. Thus, credit is a crucial factor in the determination of economic development. Alternatively, with economic development, both households and firms are more likely to demand financial services. This indicates a presence of directional relationship with economic growth impacting financial development in an economy. Besides this finance-growth nexus, financial stability is also a significant factor in the determination of macroeconomic performance.

A similar study on the establishment of association between economic performance, financial depth, and financial stability in the European Union from I998 to 20 I I was conducted by (Creel, Hubert, \& Labondanc, 2015) by employing the framework of (Beck \& Levine, 2004). The analysis revealed the absence of a significant positive impact of financial depth on 
economic performance and its constituents namely, consumption, disposable income, and investment. Further, financial instability was found to impact economic growth significant negatively.

(Al-Tarawneh \& Khataybeh, 2016) also examined the association between monetary policy and financial stability in Jordan. They employed impulse response function (IRF) using a VAR framework to test the relationship besides employing Granger Causality test. The study used the methodology of Van den End (2006) to construct a financial stability index. The analysis found that changes in excess reserves and changes in domestic credit impacted the financial stability index significant positively though of minuscule magnitude. Thus, the study found that monetary policy impacts the financial stability significant positively via the effect on its medium target, chiefly excess reserves.

Contrary results were obtained in the study examining the association of productivity growth at economy level with the size and growth of a financial system (Cecchetti \& Kharroubi, 2012). The relationship was tested on fifty advanced and emerging market economies over a period of past three decades. The analysis found that higher productivity growth was achievable with larger financial system but only at the lower levels. And when an economy is characterized with more credit and more banking, the larger financial system was found to be associated with lower growth. Subsequently, in the analysis probing the impact of growth on the financial system on real productivity growth, unambiguous evidence pointed at a negative relationship. More precisely, faster growth in finance was found to be bad for aggregate real growth. In other words, the study argued that bad trend economic growth was a consequence of financial booms.

Outcomes of similar nature were quoted in a study by (Hatzius, Hooper, Mishkin, Schoenholtz, \& Watson, 2010) which examined the link between economic activity and its financial conditions by using the Financial Conditions Index (FCI). This index included a broad range of quantitative and survey-based indicators along with asset prices and interest rates in an unbalanced panel which extended the time series back to 1970. Further, this index was used to forecast future economic activity while controlling for past inflation and GDP growth. The results indicated a tighter link of FCI with future economic activity. Interestingly by 2009 year-ending, the study highlighted the worse-than-normal levels of its FCI (index) which underlined the fact that it was a drag of crisis impact on the economic growth of the nations in 20I0. The abnormal index values were attributed to numerous quantitative credit measures which continued unusually weak for countries that had even restarted expanding.

Addressing the financial instability requires facing a challenging task of fuzziness or lack of precision with which the goal can be measured that complicates the measurement of financial stability. The study concludes that financial instability measurement with fuzziness may be challenging but it does not hinder the progress towards an effective operational framework. The only condition is that the fuzziness must be appropriately accounted for. Notwithstanding such weaknesses, (Borio \& Drehmann, 20II) defined one such framework which emphasizes certain features to make it effective. These features include higher reliance on automatic stabilizers rather than discretion, more systematic addressing of the pro-cyclicality of the financial system, the framework must have a macro-prudential orientation instead of micro-prudential orientation i.e., more significance to the financial system completely relative to individual institutions, more weightage must be accorded to institutions which are highly leveraged or with high systemic impact factor, and setting up arrangements which benefit from the expertise of various authorities or institutions involves in protecting the financial stability.

(Johnston, Schumacher, \& Chai, 2000) in their study examine the vulnerabilities in the financial system via different analytical approaches. They listed three main sources of vulnerability that badgers the financial system. The first source of vulnerability is related to the potential failures and losses in individual institutions and markets and thus is a non-diversified risk. The second type is the system-wide vulnerability which is generally associated with the contagion risk. Subsequently, third type of vulnerability is the exposure of financial system to crisis where institutions fail to absorb the shocks. Further, the authors also analyzed different elements involved in assessing financial system vulnerabilities. These include economic and incentive structure approach, risk assessment approach, supervisory approach, assessment of net risk, assessment of near-term, medium- to longerterm vulnerabilities, and an assessment of different risk-measurement techniques.

(Cheang \& Choy, 20II) in their study constructed an index for the banking sector in Macao namely, aggregate financial stability index (AFSI). The weighted average of 19 individual partial indicators representing aspects of financial stability in an economy were used to construct AFSI. The purpose was to reveal the condition of stability of the banking sector considering Early Warning System (EWS). The AFSI compiled by the authors found that banking sector of Macau has largely remained stable over the years. However, the level of financial stability was found to have deteriorated during crisis period including the global financial crisis of 2008, Asian financial crisis of 1997-98, and recession of the late 1990s compared to other periods during which AFSI stayed largely favorable.

(Fell \& Schinasi, 2005) in their study presents the challenges and practical boundaries of assessment of financial stability. According to this study, maintenance of a dynamic and sustainable economic growth mandates a framework to safeguard the financial stability of a nation. The monetary stability and macroeconomic preservation are consequences that follows a stable financial system. Consistently, the study advocated for a forward-looking approach for a timely identification of probable development of financial imbalances and consideration for diffusion lags in policy instruments as a part of the framework.

The financial system for a long time had emerged as a key policy objective of central banks of many economies. Financial stability in the study has been described as a system that manages risk and absorb shocks by efficiently allocating the resources. 
Consistent with this definition, (Houben, Kakes, \& Schinasi, 2004) developed a framework for protecting financial stability. The framework is comprised of the investigation of possible vulnerabilities and risks in financial system, examining all factors that impact functioning of financial system. It pre-dominantly included financial institutions, macro-economy, financial markets, and financial infrastructure as the factors under scrutiny, intended at early detection of financial vulnerabilities. Besides the estimation of vulnerabilities, another part of the framework outlined policy implications based upon estimated outcomes. The analysis outcome was categorized into three broad classes namely, prevention, resolution, and remedial action with the objective to sustain the financial system or restore it to its stable position.

(Roy, Biswas, \& Sinha, 2015) constructed a leading indicator and a monthly indicator, Financial Conditions Composite Indicator (FCCI). The indicator was constructed to estimate the association between economic activity and financial condition of India for a period from April 2004 to March 20I4. The study used the financial conditions indices from five different markets namely, foreign exchange market, debt market, equity market, housing market, and money market for the construction of a single index. Thereafter to remove the effect of macroeconomic fundamentals on the indicators, the feedback impact of inflation and economic growth on varied financial indicators were removed. Subsequently, residual series were subjected to PCA assisting in extracting their weights. In other words, the study used the weighted average of the factors where percentage variations explained by the factors were employed as weights to the corresponding factors. Further, the study estimated the threshold for indicators along with the stress point by using the kernel density approach. The study successfully constructed the diffusion index and the Composite Leading Indicator (CLI) for FCCI. While the diffusion index was constructed to estimate the percentage of indicators surpassing their respective threshold level, CLI successfully captured the upward movement in stress in advance.

\section{Objective and Methodology}

The objective of the underlying study is to construct four measures of financial stability (MFS) namely Measure of Economic Performance (MEP), Measure of Government Performance (MGP), Measure of External Economic Performance (MEEP), and Measure of Monetary Performance (MMP). The subsequent objective of the study is to examine the impact of MFS stability on Foreign Direct Investment (FDI) of BRIC nations

To achieve the abovementioned objective the annual data for developing the four sub-indices for MFS is taken from (Moody's, 2013), Moody's Statistical Handbook, Country Credit for the period beginning from 2000-2017. The value of the current year represents the performance of the variable in the previous year. The data for FDI inward US dollars at current price is taken from World Development Indicators International Debt Statistics. Variables used to study the effect of Measure of Financial Stability on FDI (Appendix-A: Table I).

\section{I Methodology}

\section{I.I Methodology for Construction in Indices}

To construct the Measures of Financial Stability, multivariate analysis is performed. Principal Component Analysis (PCA) as advanced by Pearson (Abdi \& Williams, 2010) is used to overcome the issue of multicollinearity, a consequence of correlation existence between the variables.

The extraction through PCA is based on Variance Maximizing Rotation, i.e. the approximation of the regression line hence minimizing the variance around new factors. The principal component transformation for the random vector $Z$ as given in (Härdle \& Hlávka, 2007) with $\mathrm{E}(\mathrm{Z})=\mu$ and $\operatorname{Var}(\mathrm{Z})=\Sigma=\Gamma \Lambda \Gamma^{\mathrm{T}}$ is

$$
Y=\Gamma^{\mathrm{T}}(Z-\mu) \quad 1
$$

Where,

- $\quad E(Z):$ is the expected value of random vector $Z$ is mean

- $\operatorname{Var}(Z)$ : is the variance in the random vector $Z$ is explained by co-variance matrix

- $\quad \Gamma \Lambda \Gamma^{\mathrm{T}}$ is a diagonal matrix and $\Gamma \Gamma^{\mathrm{T}}$ is a correlation matrix.

- $\mu$ is the Expected value of $Z$

We used (Jolliffe, I972, I973) criteria for the selection of variables wherein, only one variable from each column with maximum loading is selected to represent the principal component. PCA reproduces the variance and correlations using Eigenvalues $^{1}$ to compute the weights and analyse the variables. To retain the factors the Kaiser (I960) was adopted, where Eigen

\footnotetext{
${ }^{\mathrm{I}}$ A scalar associated with a given linear transformation of a vector space and having the property that there is some nonzero vector which when multiplied by the scalar is equal to the vector obtained by letting the transformation operate on the vector. In general, the eigenvector $\mathrm{v}$ of a matrix A is the vector for which the following holds:

$\vec{v}(A-\lambda I)=0$

Where $\lambda$ is a scalar value called the 'eigenvalue'. This means that the linear transformation A on vector v is completely defined by $\lambda$ and where I is the identity matrix of the same dimensions as A
} 
value is greater than one. The four measures of financial stability are constructed by summing the multiplication of each of the variable with its respective factor loading with the following equation:

- Measure of Economic Performance (MEP) $=\sum_{j=1}^{n} w_{j} z_{j}$

- Measure of Government Performance (MGP) $=\sum_{j=1}^{n} w_{j} z_{j}$

- Measure of External Economic Performance (MEEP) $=\sum_{j=1}^{n} w_{j} z_{j}$

- Measure of Monetary Performance (MMP) $=\sum_{j=1}^{n} w_{j} z_{j}$
(Eq $2($ i) )

(Eq 2 (ii))

(Eq 2 (iii))

(Eq 2 (iv))

3.I.2 Methodology for testing the Composite Indices in a Regression Framework where the dependent variable is foreign direct investment

To handle the endogeneity dilemma, we used TSLS procedure. It is a two-step regression analysis, wherein the first stage exogenous explanatory variables are estimated, and then predicted values are calculated. In the second stage these predicted values are deputed in the structural equation model. Equations 4 and 5 are the two stages in TSLS regression as given by (Katchova, 2013):

Where;

$$
\begin{aligned}
& y_{2}=x^{\prime}{ }_{1} \gamma_{1}+x^{\prime}{ }_{2} \gamma_{2}+e \\
& y_{1}=\hat{y}^{\prime}{ }_{2} \beta_{1}+x^{\prime}{ }_{1} \beta_{2}+\mu
\end{aligned}
$$

- $y_{1}$ is the Dependent Variable

- $y_{2}$ is the Endogenous Variables

- $x_{1}$ is the Exogenous Variable and is an instrument for itself

- $\quad x_{2}^{\prime}$ is the Instrument for $y_{2}$

For deciding the IV we have to make sure that the following conditions are fulfilled namely, IV must be correlated with the variables that need to be instrumented (IV must be correlated with the included endogenous variables) and they are uncorrelated with the error term (orthogonal to error term). The conventional IV estimator, though consistent is however inefficient in the presence of heteroskedasticity. Hence, we have used generalized methods of movements (GMM) introduced by (Hansen, I982). If heteroskedasticity is present, the GMM estimator is more efficient than the simple IV estimator.

\section{Post Estimation Test}

$\mathrm{C}$ test is used to test a variety of combinations of the orthogonality conditions, not only those involving regressors but those involving excluded instruments as well. The null hypothesis is that the variables are exogenous. The same should be rejected. Over identifying restrictions in GMM is tested via J statistic of (Hansen, I982). J statistic is distributed as a chi-square with p degree of freedom equal to the number of over-identifying restrictions $L-K$ rather than the total number of moments conditions $L$ because, in effect, $K$ degree of freedom is used up in estimating the coefficients of beta (set of regressors $(K)$ and set of Instrumental variables $(L)$. The null hypothesis of the $\mathrm{J}$ statistic is the instrument set is valid and model is correctly specified. A rejection of the null hypothesis implies that the instruments are not satisfying the orthogonality conditions required for their employment. This may be either because they are not truly exogenous, or because they are being incorrectly excluded from the regression. Hence the null hypothesis should be accepted. The weak instrument problem arises when the correlation between the endogenous regressors and the excluded instruments are non-zero but small. The F statistic proposed by (Stock \& Yogo, 2005) is used to test the weak instruments. The null hypothesis is that the instruments do not suffer from the specified bias. Rejection of the null hypothesis represents the absence of a weak instruments problem.

\section{Analysis and Interpretation}

\section{I Construction of Principal Component Analysis}

When PCA is applied on a total of thirteen economic performance indicators, fourteen external performance indicators, nine government performance indicators, and ten monetary indicators variables, separately KMO value is reported in (Appendix-B: Table 2). Those PCA outputs were selected which had the KMO-value greater than 0.6. It was also ensured that the "Total Variance" explained (in \%) is more than 90 percent. The total variance explained value is reported in (Appendix-B:Table 2).

The component scores which was taken as weights for the construction of four financial stability measures are indicated in (Appendix-C:Table 3). The respective component scores which were obtained by Varimax with the Kaiser Normalization rotation method was multiply with the respective value of the variables. For example, population is multiplied by 0.919, gross domestic savings by 0.898 , inflation by 0.922 , and government effectiveness by 0.959 . After that, all the multiplied values were added to construct the Economic Sector Performance Measure. Likewise, other three measures were also constructed. It was pragmatic that augment in the value of all the four constructed measures will boost financial stability (Appendix-C: Table 3).

\subsection{Results of Two-Stage Least Square Regression Framework}

In a 2SLS regression framework, the independent variables consist of nominal GDP and four measures of financial stability (MFS) that are constructed as composite measures, through PCA and openness of the economy. The second set of variables consists of 
exogenous variables that have in the subsequent equation been incorporated and subsumed within 'Openness of the Economy'. This has been designed as an (IV) instrument variable, which, in turn, depends on a set of exogenous variables (Nominal Exchange Rate local currency, External Debt US \$ Bill, Short-term External Debt Total, Monetary Policy Rate per annum, Current Account Balance in US Bill, Domestic Credit change Dec De, General Government Debt US Bill, Dollarization Ratio, Liquidity Ratio, Nominal exports and imports of goods and services, general government primary and financial Balance). Through the impact of these variables 'Openness of the Economy' gets determined. Further, the predicted value of the 'Opens variable' shall enter the final equation as an Instrument Variable (IV). We shall first discuss the (IV) briefly, in general terms. The question precisely is, as to how these exogenous variables lead to openness. First, the nominal exchange rate leads to openness. A rise in the nominal exchange rate will encourage exports in the eyes for the foreigner. Second, external debt will surely affect openness. This is because the indebted country would have to throw-off the debt. This involves a further boost to exports which improves foreign exchange rates and reserves. This implies openness. Third, Short Term debt would also have the same impact on openness. Monetary Policy would affect inflation and in turn, it would affect purchasing power that, in turn, would affect the exchange rate and hence, openness. The current account balance is a clear indicator of openness. The impact of domestic credit is like that of Monetary Policy. Government Debt would lead to a weakening of the domestic currency and hence affect the exchange rate and thus, would affect openness. Liquidity acts just like credit. Dollarization also directly affects openness. It needs to be noted that there is no stipulation that the impact on openness has to be positive. The variables may affect openness either way - positively or negatively (Appendix-D: Table 4).

\section{Brazil}

In the case of Brazil all four measures namely MEP, MGP, MEEP, and MMP of financial stability are significant at $1 \%$. The results also indicate that nominal GDP and Openness of the economy also impact FDI inwards flows. An increase in Nominal Exports of Goods and Services, GDP Per Capita, Gross Domestic Savings to GDP, and Government Effectiveness increase the inward FDI flows. External Debt/GDP, Net Foreign Assets of Domestic Banks (US \$ Billion), Current Account Balance/GDP, and Real Effective Exchange Rate (\% change) positively impact the FDI. General Government Financial Balance/GDP, General Government Interest Payment /General Government Revenue, and General Government Revenue/GDP also have a positive impact on FDI flows. The difference between total revenues and total expenditures can be met only by running down assets or from borrowing, thereby, adding to the debt. In the case of Brazil, the financial balance (surplus or deficit) concerning GDP is moderate except for the year 20I5. General Government Interest Payments/General Government Revenue, focuses on the degree to which past debt accumulation and the interest rate paid on government debt drains revenue towards debt service and away from the provision of government services, is moderate except for the period 2015.

M2 (\% change Dec/Dec) measures the rapid growth of the stock of money circulating within a country may be an indicator of future inflationary pressure that can undermine confidence in the currency and lead to a run into foreign currency assets. Or it may simply be a sign of deepening financial intermediation. The analyst needs to look at this variable in the context of a country's overall financial development. Liquidity Ratio and Domestic Credit (\% Change Dec /Dec). External Vulnerability Indicator in the case of Brazil signifies that the country's immediately available foreign exchange resources are sufficient to allow it to make all external debt payments, even if there is a complete refusal of creditors to roll over debt due within a given year.

\section{Russia}

In the case of Russia MEP and MMP positively impact inward FDI and are significant at I \%. MGP turns out to be significant but it is negatively impacting the FDI inflows. As far as MEEP is concerned it is not significant. FDI flows also depend upon the GDP and openness of the economy. A moderate rate of inflation, nominal imports of goods and services and government effectiveness increase the FDI inflows.

The ratio of general government primary balance-to-GDP presents the ratio of the primary budget balance-to-GDP, which is the difference between total revenues and total expenditures excluding interest payments on debt. The primary balance plays a key role in the dynamics of debt growth or reduction. General government foreign currency, ratio of FC-indexed debt-togeneral government debt measures the extent to which central governments have recourse to issuing in currencies other than their own or indexing domestic-currency debt to the exchange rate. These practices often reflect either a lack of a domestic currency securities market or a lack of investor confidence in the domestic currency resulting from expectations of high inflation. A high ratio can signal potential debt-servicing stress in the event of a major exchange-rate adjustment, even when other measures like debt-to-GDP ratio or debt-to-revenue ratio may appear low. In the case of Russia, these measures are not effectively regulated hence adversely affecting the FDI. In case of Russia, the general government debt-to-general government revenue ratio is also high. Government finance represents the hindrance to FDI and implies that there is mismanagement of government of finance.

The monetary policy rate is the central bank's monetary policy target rate or other rates such as deposit rates, overnight lending rates, or other lending rates. Interest rates are among the most important macroeconomic variables, influencing saving, investing, lending, and borrowing decisions across the entire economy. In particular, a rapid run-up to very high-interest rates often associated with simultaneous currency depreciation - can severely stress debtors, whether government or corporate, raising 
the risk of bankruptcy and default. "Dollarization" Vulnerability Indicator assists in detection of added risk of default and payment crisis resulting from the existence of "dollarized" glut in the domestic banking system. The numerator is represented by foreigncurrency deposits which essentially contributes to a capital flight in response to the increasing risk perception about a banking crisis in an economy. Alternatively, denominator denotes might of the financial system to withstand such capital flight even if it means draining central bank's foreign-currency reserves and on-balance-sheet foreign assets of the banking system. In the case of Russia, both these two indicators are judicious and hence not endangering the economy towards crises.

\section{China}

In the case of China MGP, MEEP, and MMP turn out to be significant at I\%. MEP does not turn out to be significant. General government revenue-to-GDP ratio is high whereas general government debt-to-general government revenue ratio is low for China. General government interest payment-to-general government revenue ratio emphases the drain of government revenue to service of old debt, away from the provision of government services and which was found to be judicious for China. This may be the cause of a substantial FDI contribution observed in their economy relative to others. Nonetheless, the apparent effective management of finances in the case of China can also be hailed as another reason for greater investor confidence leading to upsurged FDI inflows. Alternatively, certain factors also have a negative impact on their FDI inflows. These factors are interest paid on external debt, short term external debt to total external debt ratio, and amortization that cast a shadow of doubt on investor confidence resulting from the ambiguity surrounding the foreign exchange rate of Chinese currency. The analysis found that burden of external debt can effectively be measured from the ratio of total external debt-to-official foreign exchange reserves. The monetary policy rates are found to be associated with currency depreciation and emerging instrumental in severely draining the debtors leading to an increased risk of default and bankruptcy.

External Vulnerability Indicator indicates enough foreign exchange reserve to finance all due external debt payments. Furthermore, it is a measure of financial capacity to endure sudden shortfall of investor confidence emerging from general liquidity crunch or increased risk perception in the markets. A high ratio may indicate increased vulnerability caused by an extreme shortterm debt or grave clustering of repayments on long-term debt. Nevertheless, it is advised to exhaustively scrutinize the composition of short-term debt, particularly in the case of China. It is because China is a key commodity exporter in the world and thus may have high volume of trade-related short-term debt which is not as vulnerable to withdrawals as interbank credit lines. Monetary policy broadly plays a negative role in attracting FDI inflows. When it comes to the external sector, the main hurdle is China's exchange rate policy and hence a mist on its foreign exchange reserves, which is adversely impact its FDI inflows.

\section{India}

In the case of India three measures of financial stability namely MEP is significant at I\%, MGP is significant at 5\%, and MEEP significant at I0\%. MMP does not turn out to be significant. Gross investment/GDP, nominal imports of goods and services, and nominal GDP are contributing positively to increase the FDI flows. General government debt-to-general government revenue ratio, general government revenue-to-GDP ratio, general government financial balance-to-GDP and general government foreign currency ratio, and FC-Indexed debt-to-general government debt ratio contributes negatively for attracting FDI inflows. In the case of India as far as government finances are concerned, they are not effectively managed. Despite this, foreign investors invest in India because the overall economic performance measures are effective. Official foreign exchange reserves held by RBI, the central bank of India is sufficient and act as a defense against the withdrawal of foreign credit. The external debt-to-GDP ratio is one vital contributor in the future interest payment flows that the country's residents will have to pay to non-residents over time. Short term external debt/ total external debt is a simple measure of maturity risk reflecting the proportion of debt with original maturity of less than one year. In the case of India both these two measures are well-managed and hence contributes positively to attracting the FDI flows.

\section{Post Estimation Test}

The post estimation test of the TSLS model is reported in (Appendix-E: Table 5). The test of endogeneity was significantly rejected, validating that there is endogeneity problem and hence application of 2SLS was justified. The test of weak instruments was rejected, which indicates that the instruments are not weak, they are further amplifying the behaviors of foreign direct investment. As mentioned in methodology, null hypothesis of over-identified restrictions should be established, proposing thereby that the instrument set is convincing, and the model is appropriately specified.

\section{Conclusion}

In the case of Brazil, all four measures of financial stability are significant. In the case of Russia, government finances are not appropriately managed, yet, the economy is able to magnetize FDI. The reason may be accorded to the fact that other measures emerge to be effective and optimistically contributing towards the stability of the economy. In the case of China, the large inflow of FDI is because of government policies as the rest of the measures are negative. In the case of China, economic failures appear on monetary and fiscal performance as this measure is neither significant nor contributing positively towards FDI. In the case of 
India, the government measures are not efficient to attract the FDI. The devil is government fiscal policy that is large, significant, and negative. The openness of the economy is positively contributing to FDI in all countries except India. Meaning thereby that the Indian government must work towards opening of the economy. The subsequent severest outcome is a monetary policy that is also negative, but neither significant nor large. In the case of India and China, policy malfunction appears on the monetary front. Of all the four nations Brazil is on the right track.

The external sector is well-managed in the case of Brazil and India. The monetary policies are well implemented in the case of Brazil and Russia. Russia and India's government finances need to be managed more effectively. It is a blessing in disguise. If we recognize that in the case of emerging economies, they do not have policy independence in the international sphere, such a result is not surprising. The result clearly shows policy failure exists in the case of Russia and monetary failure appears in the case of China.

\section{References}

Abdi, H., \& Williams, L. J. (2010). Principal component analysis. Wiley Interdisciplinary Reviews: Computational Statistics, 2(4), 433-459. https://doi.org/I0.I002/wics.IOI

Al-Tarawneh, A., \& Khataybeh, M. (2016). Impact of Monetary Policy on Financial Stability Evidence from Jordan = أثر السياسة . Dirasat Administrative Sciences, 43(I), 30I-313. https://doi.org/I0.12816/0028464

Aspachs, O., Goodhart, C., Segoviano, M., Tsomocos, D., Zicchino, L., Group, F. M., \& Industry, F. (2006). Searching for a Metric for Financial Stability. Lse Financial Markets Group Special Paper Series, I67, I-38.

Bank for International Settlements. (2010). Macroprudential policy tools and frameworks. Update to G20 Finance Ministers and Central Bank Governors. Financial Stability Board.

Beck, T., \& Levine, R. (2004). Stock markets, banks, and growth: Panel evidence. Journal of Banking and Finance. https://doi.org/I0.1016/S0378-4266(02)00408-9

Borio, C. E. V., \& Drehmann, M. (20I I). Towards an Operational Framework for Financial Stability: "Fuzzy” Measurement and Its Consequences. SSRN Electronic Journal, 284. https://doi.org/I0.2139/ssrn.I458294

Cecchetti, S. G., \& Kharroubi, E. (20I2). Reassessing the impact of finance on growth. BIS Working Paper.

Cheang, N., \& Choy, I. (20I I). Aggregate Financial Stability Index for an Early Warning System. 27-5I.

Creel, J., Hubert, P., \& Labondance, F. (2015). Financial stability and economic performance. Economic Modelling. https://doi.org/I0.I0I6/j.econmod.20I4.I0.025

Daniel, B. C., \& Jones, J. B. (2007). Financial Liberalization and Banking Crises in Emerging Economies. Journal of International Economics, $72(\mathrm{I}), 202-2 \mathrm{I}$.

Enowbi, M. B., \& Kupukile, M. (2012). Financial instability, financial openness and economic growth in african countries. University of Westminster, African Development Bank, (43340).

Erturk, K. A. (2005). Economic Volatility and Capital Account Liberalization in Emerging Countries. International Review of Applied Economics, I9(4), 399-4I7.

Fell, J., \& Schinasi, G. (2005). Assessing financial stability: Exploring the boundaries of analysis. National Institute Economic Review, I92(I), I02-I17. https://doi.org/I0.I177/0027950105192001 I0

Goodhart, C. A. E., Sunirand, P., \& Tsomocos, D. P. (2005). A model to analyse financial fragility. Economic Theory. https://doi.org/I0.1007/s00199-004-0572-7

Härdle, W., \& Hlávka, Z. (2007). Multivariae Statistics: Excercise and Solutions.

Hatzius, J., Hooper, P., Mishkin, F., Schoenholtz, K. L., \& Watson, M. W. (20I0). Financial Conditions Indexes : A Fresh Look after the Financial Crisis. NBER Working Paper, No. I6150(0340-576I LA-eng), 652-660. https://doi.org/I0.2139/ssrn.3I5489

Hansen, L. P. (1982). Large sample properties of generalized method of moments estimators. Econometrica: Journal of the Econometric Society, I029-I054.

Houben, A., Kakes, J., \& Schinasi, G. (2004). Toward a Framework for Safeguarding Financial Stability. IMF Working Papers, O4(IOI), I. https://doi.org/I0.5089/978I45I852547.00I

Johnston, R. B., Schumacher, L., \& Chai, J. (2000). Assessing Financial System Vulnerabilities. IMF Working Papers. https://doi.org/I0.5089/9781451849868.001

Jolliffe, I. T. (I972). Discarding Variables in a Principal Component Analysis. I: Artificial Data. Applied Statistics. https://doi.org/I0.2307/2346488

Jolliffe, I. T. (1973). Discarding Variables in a Principal Component Analysis. II: Real Data. Applied Statistics. https://doi.org/I0.2307/2346300

Kaiser, H. F. (1960). The Application of Electronic Computers to Factor Analysis. Educational and Psychological Measurement. https://doi.org/IO.I I77/00I3I6446002000II6

Kaminsky, G. L., \& Schmukler, S. L. (2008). Short-Run Pain, Long-Run Gain: Financial Liberalization and Stock Market Cycles. Review of Finance, I2(2), 253-92. 
Katchova, A. (2013). Instrumental Variables. https://doi.org/I0.1097/0I.ede.0000215160.88317.cb

Kim, E. H., \& Singal, V. (2000). The Fear of Globalizing Capital Markets. Emerging Markets Review, I(3), I83-98.

Moody's. (2013). Moody's Statistical Handbook Country Credit (Issue November).

Roy, I., Biswas, D., \& Sinha, A. (2015). Financial Conditions Composite Indicator ( FCCI ) for India. Indicators to Support Monetary and Financial Stability Analysis : Data Sources and Statistical, 7(IFC Bulletin 39).

Stock, J. H., \& Yogo, M. (2005). Testing for weak instruments in Linear Iv regression. In Identification and Inference for Econometric Models: Essays in Honor of Thomas Rothenberg. https://doi.org/I0.1017/CBO97805I 16I4491.006

Tsomocos, D. P. (2003). Equilibrium analysis, banking and financial instability. Journal of Mathematical Economics. https://doi.org/I0.I0I6/S0304-4068(03)00045-4

Tsomocos, D. P. (2005). Equilibrium Analysis, Banking, Contagion and Financial Fragility. SSRN Electronic Journal. https://doi.org/I0.2139/ssrn.38I I40

Van den End, J. W. (2006). Indicator and boundaries of financial stability. DNB Working Paper.

\section{Appendices}

Appendix-A: Table I. Variables used to study the impact of Measure of Financial Stability on Foreign Direct Investment

\begin{tabular}{|c|c|c|c|}
\hline Sr. No. & Name of the Variable and Index & \multicolumn{2}{|l|}{ Source of Definition } \\
\hline \multicolumn{4}{|c|}{ I. Growth : Dependent Variable } \\
\hline $\mathrm{I}$ & FDI inward US dollars at current prices & \multicolumn{2}{|l|}{ UNCTAD } \\
\hline \multicolumn{4}{|c|}{ 2.Measures of Financial Stability : Explanatory Variable } \\
\hline $\mathrm{I}$ & Measure of Economic Performance (MEP) & \multirow{4}{*}{\multicolumn{2}{|c|}{ Developed By Authors }} \\
\hline II & Measure of Government Performance (MGP) & & \\
\hline III & Measure of External Economic Performance (MEEP) & & \\
\hline IV & Measure of Monetary Performance (MMP) & & \\
\hline $\mathrm{V}$ & Gross Domestic Product Current Price & \multicolumn{2}{|c|}{ World Economic Outlook } \\
\hline VI & Nominal Gross Domestic Product (\%Change, Local currency) & \multirow{20}{*}{$\begin{array}{l}\text { Moody's Statistical } \\
\text { Country Credit }\end{array}$} & \multirow{20}{*}{ Handbook } \\
\hline VII & Openness of the Economy & & \\
\hline VIII & External Debt (US\$ Billion) & & \\
\hline IX & Short term External Debt/ Total External Debt & & \\
\hline $\mathrm{X}$ & Monetary Policy Rate (\%per annum, Dec 3I) & & \\
\hline XI & Nominal Exchange Rate (local currency per US\$, Dec) & & \\
\hline XII & Current account balance (US\$ Billion) & & \\
\hline XIII & Real Effective Exchange Rate (\% change) & & \\
\hline XIV & General government Debt (US\$ Billion) & & \\
\hline $\mathrm{XV}$ & General Government Debt/ GDP & & \\
\hline XVI & Domestic Credit (\% Change Dec /Dec) & & \\
\hline XVII & Nominal Exports of Goods and Services (\% change, US\$) & & \\
\hline XVIII & Nominal Imports of Goods and Services (\% change, US\$) & & \\
\hline XIX & General Government Primary Balance/GDP & & \\
\hline $\mathrm{XX}$ & General Government Financial Balance/GDP & & \\
\hline XXI & Population (Mil) & & \\
\hline XXII & Inflation (CPI, \% change Dec/Dec) & & \\
\hline XXIII & Public Sector External Debt/ Total External Debt & & \\
\hline XXIV & "Dollarization" Ratio & & \\
\hline XXV & Government Effectiveness & & \\
\hline
\end{tabular}


Appendix-B: Table 2. KMO Value and Total Variance Explained

\begin{tabular}{|c|c|c|c|}
\hline S.No. & Name of the Index & KMO Value & $\begin{array}{l}\text { Total Variance } \\
\text { explained (in \%) }\end{array}$ \\
\hline \multicolumn{4}{|l|}{ Brazil } \\
\hline $\mathrm{I}$ & Measure of Economic Performance (MEP) & 0.687 & 95.626 \\
\hline 2 & Measure of Government Performance (MGP) & 0.807 & 100 \\
\hline 3 & Measure of External Economic Performance (MEEP) & 0.605 & 96.596 \\
\hline 4 & Measure of Monetary Performance (MMP) & 0.738 & 94.566 \\
\hline \multicolumn{4}{|c|}{ Russia } \\
\hline I & Measure of Economic Performance (MEP) & $0.7 \mathrm{I3}$ & 95.307 \\
\hline 2 & Measure of Government Performance (MGP) & 0.668 & 99.354 \\
\hline 3 & Measure of External Economic Performance (MEEP) & 0.683 & 94.309 \\
\hline 4 & Measure of Monetary Performance (MMP) & 0.67 & 97.229 \\
\hline \multicolumn{4}{|l|}{ India } \\
\hline I & Measure of Economic Performance (MEP) & $0.7 \mathrm{I} 4$ & 89.275 \\
\hline 2 & Measure of Government Performance (MGP) & 0.648 & 99.802 \\
\hline 3 & Measure of External Economic Performance (MEEP) & 0.718 & 89.979 \\
\hline 4 & Measure of Monetary Performance (MMP) & 0.643 & 90.215 \\
\hline \multicolumn{4}{|l|}{ China } \\
\hline I & Measure of Economic Performance (MEP) & 0.704 & 93.576 \\
\hline 2 & Measure of Government Performance (MGP) & 0.691 & 98.703 \\
\hline 3 & Measure of External Economic Performance (MEEP) & 0.697 & 97.32 \\
\hline 4 & Measure of Monetary Performance (MMP) & 0.662 & 98.289 \\
\hline
\end{tabular}

Source: Authors Calculation

Appendix-C: Table 3. Component Weights

\begin{tabular}{|c|c|c|c|}
\hline $\begin{array}{l}\text { S. No. } \\
\text { of Index }\end{array}$ & $\begin{array}{l}\text { S.No. } \\
\text { Var }\end{array}$ & Variables & Weight \\
\hline \multicolumn{4}{|l|}{ Brazil } \\
\hline \multirow[t]{5}{*}{ I } & \multicolumn{3}{|c|}{ Measure of Economic Performance (MEP) } \\
\hline & i & Nominal Exports of Goods and Services & 0.887 \\
\hline & ii & GDP Per Capita (Purchasing Power Parity, US \$) & 0.957 \\
\hline & iii & Gross Domestic Savings to GDP & 0.88 \\
\hline & iv & Government Effectiveness & 0.897 \\
\hline \multirow[t]{4}{*}{2} & \multicolumn{3}{|c|}{ Measure of Government Performance (MGP) } \\
\hline & $\mathrm{i}$ & General Government Financial Balance/GDP & 0.827 \\
\hline & ii & General Government Interest Payment /General Government Revenue & 0.933 \\
\hline & iii & General Government Revenue/GDP & 0.852 \\
\hline \multirow[t]{3}{*}{3} & \multicolumn{3}{|c|}{ Measure of External Economic Performance (MEEP) } \\
\hline & $\mathrm{i}$ & External Debt/GDP & 0.961 \\
\hline & ii & Net Foreign Assets of Domestic Banks (US \$ Billion) & 0.906 \\
\hline
\end{tabular}




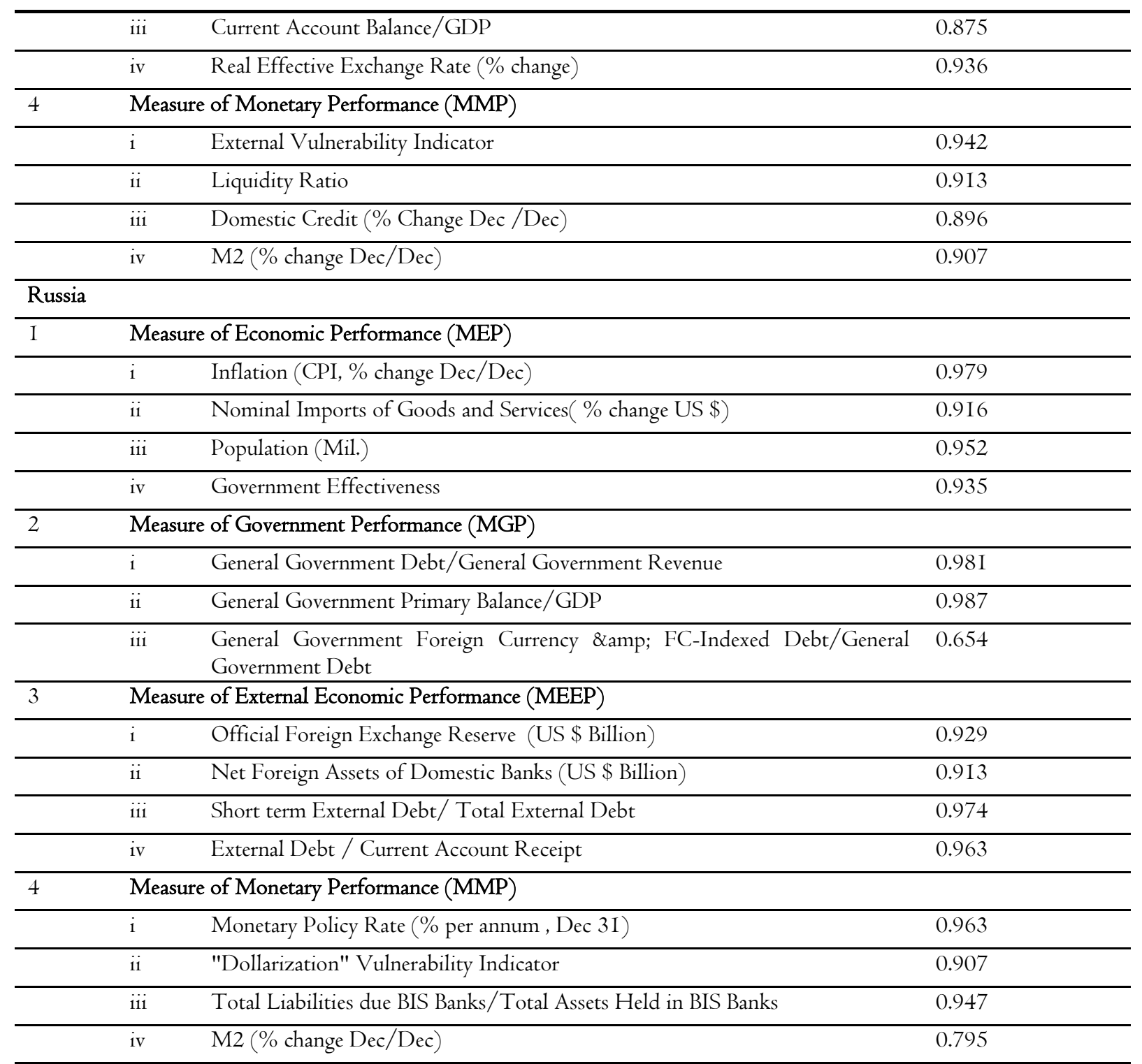

\begin{tabular}{llll}
\hline China & & & \\
\hline I & Measure of Economic Performance (MEP) & 0.905 \\
\hline & i & Gross Investment/GDP & 0.851 \\
\hline & ii & Nominal Exports of Goods and Services (\% change US\$) & 0.889 \\
\hline & iii & Inflation (CPI, \% change Dec/Dec) & 0.853 \\
\hline iv & Government Effectiveness & 0.917 \\
\hline Measure of Government Performance (MGP) & 0.97 \\
\hline i & General Government Revenue/GDP & 0.616 \\
\hline ii & General Government Interest Payment/ General Government Revenue & 0.969 \\
\hline
\end{tabular}




\begin{tabular}{|c|c|c|c|}
\hline & iii & Interest Paid on External Debt (US \$Billion) & 0.966 \\
\hline \multirow[t]{5}{*}{4} & \multicolumn{3}{|c|}{ Measure of Monetary Performance (MMP) } \\
\hline & I & Total External Debt /Official Foreign Exchange Reserves (US\$ Bil.) & 0.899 \\
\hline & ii & Liquidity Ratio & 0.863 \\
\hline & iii & Monetary Policy rate (\% per annum, Dec 3I) & 0.944 \\
\hline & iv & External Vulnerability Indicator & 0.872 \\
\hline \multicolumn{4}{|c|}{ India } \\
\hline \multirow[t]{4}{*}{ I } & \multicolumn{3}{|c|}{ Measure of Economic Performance (MEP) } \\
\hline & $\mathrm{i}$ & Gross Investment/GDP & 0.922 \\
\hline & ii & Nominal GDP (US \$ Billion) & 0.883 \\
\hline & iii & Nominal Imports of Goods and Services \% change US \$ & 0.959 \\
\hline \multirow[t]{5}{*}{2} & \multicolumn{3}{|c|}{ Measure of Government Performance (MGP) } \\
\hline & $\mathrm{i}$ & General Government Debt/General Government Revenue & 0.916 \\
\hline & ii & General Government Revenue/GDP & 0.931 \\
\hline & iii & General Government Financial Balance/GDP & 0.8 \\
\hline & iv & $\begin{array}{l}\text { General Government Foreign Currency \&amp; FC-Indexed Debt/General } \\
\text { Government Debt }\end{array}$ & 0.758 \\
\hline \multirow[t]{4}{*}{3} & \multicolumn{3}{|c|}{ Measure of External Economic Performance (MEEP) } \\
\hline & $\mathrm{i}$ & Official Foreign Exchange Reserves (US\$ Bil.) & 0.821 \\
\hline & ii & External Debt/GDP & 0.956 \\
\hline & iii & Short-term External Debt/ Total External Debt & 0.839 \\
\hline \multirow[t]{4}{*}{4} & \multicolumn{3}{|c|}{ Measure of Monetary Performance (MMP) } \\
\hline & i & Total Liabilities due BIS Banks/Total Assets Held in BIS Banks & 0.973 \\
\hline & ii & Total External Debt /Official Foreign Exchange Reserves (US\$ Bil.) & 0.906 \\
\hline & iii & External Vulnerability Indicator & 0.701 \\
\hline
\end{tabular}

$$
\text { Source: Authors Calculation }
$$

Appendix-D: Table 4. Impact of Financial Stability Measure on FDI inward US dollar at current price

\begin{tabular}{|c|c|c|c|}
\hline Brazil & Russia & India & China \\
\hline $\begin{array}{ll}\text { Instrumental } & \text { variables } \\
(\text { GMM) regression } & \\
\end{array}$ & $\begin{array}{l}\text { Instrumental variables } \\
(\mathrm{GMM}) \text { regression }\end{array}$ & $\begin{array}{l}\text { Instrumental variables } \\
\text { (GMM) regression }\end{array}$ & $\begin{array}{l}\text { Instrumental variables (GMM) } \\
\text { regression }\end{array}$ \\
\hline $\begin{array}{l}\text { Dependent Variable: FDI } \\
\text { inward US dollars at current }\end{array}$ & $\begin{array}{l}\text { Dependent Variable: FDI } \\
\text { inward US dollars at current }\end{array}$ & $\begin{array}{l}\text { Dependent Variable: } \\
\text { FDI inward US dollars } \\
\text { at current }\end{array}$ & $\begin{array}{l}\text { Dependent Variable: FDI } \\
\text { inward US dollars at current }\end{array}$ \\
\hline GMM weight matrix: Robust & $\begin{array}{l}\text { GMM weight matrix: } \\
\text { Robust }\end{array}$ & $\begin{array}{l}\text { GMM weight matrix: } \\
\text { Robust }\end{array}$ & GMM weight matrix: Robust \\
\hline Number of obs. $=\mathrm{I} 8$ & Number of obs. $=\mathrm{I} 8$ & Number of obs. $=\mathrm{I} 8$ & Number of obs. $=\mathrm{I} 8$ \\
\hline Wald chi2(6) $=\mathrm{I} 458.97$ & Wald chi2 $(6)=566.94$ & $\begin{array}{l}\text { Wald } \quad \operatorname{chi2(6)} \\
=\mathrm{I} 46.85\end{array}$ & Wald chi2(6) $=$ I700.I3 \\
\hline Prob. $>$ chi2 $=0.0000$ & Prob. $>$ chi2 $=0.0000$ & Prob. $>$ chi $2=0.0000$ & Prob. $>$ chi $2=0.0000$ \\
\hline R-squared $=0.8995$ & R-squared $=0.7090$ & R-squared $=0.8018$ & R-squared $=0.9658$ \\
\hline Variables $\quad \mathrm{P}>|\mathrm{z}|$ & $\mathrm{P}>\mid \mathrm{z}$ & $\mathrm{P}>|\mathrm{z}|$ & Variables \\
\hline
\end{tabular}




\begin{tabular}{|c|c|c|c|c|}
\hline $\begin{array}{l}\text { Opennes } 0.0110 \\
\mathrm{~s} \text { of the } \\
\text { Economy }\end{array}$ & $\begin{array}{l}\text { Openness of } 0.00 \mathrm{I} \\
\text { the Economy }\end{array}$ & $\begin{array}{l}\text { Openness of } 0.000 \\
\text { the Economy }\end{array}$ & $\begin{array}{l}\text { Openness } \\
\text { of the } \\
\text { Economy }\end{array}$ & 0.000 \\
\hline 0.0000 & 0.001 & $\begin{array}{ll}\text { Gross domestic } & 0.002 \\
\text { product current } & \\
\end{array}$ & MSP & 0.499 \\
\hline 0.0030 & 0.000 & 0.001 & MGP & 0.013 \\
\hline 0.0000 & MEEP & $0.02 \mathrm{I}$ & MEEP & $0.01 \mathrm{I}$ \\
\hline 0.0290 & MMP & MEEP & MMP & 0.000 \\
\hline $\begin{array}{ll}\text { Nominal } & 0.0000 \\
\text { GDP } & \\
\text { change } & \\
\text { local } & \\
\text { currency } & \\
\end{array}$ & $\begin{array}{ll}\text { Nominal } & 0.035 \\
\text { GDP change } & \\
\text { local currency } & \end{array}$ & MMP & $\begin{array}{l}\text { Gross } \\
\text { domestic } \\
\text { product } \\
\text { current } \\
\text { (US\$) } \\
\end{array}$ & 0.000 \\
\hline $\begin{array}{cc}\text { cons } & 0.0010\end{array}$ & - cons & 0.017 & - cons & 0.728 \\
\hline $\begin{array}{l}\text { Instrumented: Openness of } \\
\text { the Economy }\end{array}$ & $\begin{array}{l}\text { Instrumented: Openness of } \\
\text { the Economy }\end{array}$ & $\begin{array}{l}\text { Instrumented: } \\
\text { Openness of the } \\
\text { economy }\end{array}$ & $\begin{array}{l}\text { Instrument } \\
\text { economy }\end{array}$ & Openness of the \\
\hline Instruments: & Instruments: & Instruments: & Instruments & \\
\hline $\begin{array}{l}\text { Inflation (CPI,\%change Dec/ } \\
\text { Dec) }\end{array}$ & $\begin{array}{l}\text { Nominal Exchange Rate } \\
\text { (local currency per US } \$ \text {, } \\
\text { Dec) }\end{array}$ & $\begin{array}{ll}\text { te } & \text { Nominal Exchange } \\
\text { Rate (local currency } \\
\text { per US\$, Dec) }\end{array}$ & $\begin{array}{l}\text { Real Eff } \\
\text { Rate(\%char }\end{array}$ & e) Exchange \\
\hline $\begin{array}{l}\text { Nominal Imports of Goods } \\
\text { and Services (\% change, US \$) }\end{array}$ & $\begin{array}{lll}\text { External } & \text { Debt } & \text { (US\$ } \\
\text { Billion) } & & \\
\end{array}$ & $\begin{array}{l}\text { Monetary Policy Rate } \\
\text { (\% per annum) }\end{array}$ & External D & US\$ Billion.) \\
\hline Population (Mil.) & $\begin{array}{l}\text { Domestic Credit (\% change } \\
\text { Dec/Dec) }\end{array}$ & $\begin{array}{l}\text { Public sector external } \\
\text { debt/ Total External } \\
\text { Debt }\end{array}$ & $\begin{array}{l}\text { General } \\
\text { GDP }\end{array}$ & ernment Debt \\
\hline $\begin{array}{l}\text { General Government Primary } \\
\text { Balance/ GDP }\end{array}$ & $\begin{array}{l}\text { General Government Debt } \\
\text { (US\$ Billion) }\end{array}$ & $\begin{array}{l}\text { Domestic Credit (\% } \\
\text { change Dec/Dec) }\end{array}$ & $\begin{array}{l}\text { Domestic } \\
\text { Dec/Dec) }\end{array}$ & edit (\% change \\
\hline $\begin{array}{l}\text { General Government Debt } \\
\text { (US\$ Billion.) }\end{array}$ & $\begin{array}{l}\text { Current Account Balance } \\
\text { (US \$ Billion) }\end{array}$ & $\begin{array}{l}\text { General Government } \\
\text { Debt (US \$ Billion) }\end{array}$ & $\begin{array}{l}\text { Nominal Ex } \\
\text { Services }(\% \\
\end{array}$ & $\begin{array}{l}\text { orts of Goods and } \\
\text { lange, US \$) }\end{array}$ \\
\hline $\begin{array}{l}\text { Current Account Balance US \$ } \\
\text { Billion. }\end{array}$ & $\begin{array}{l}\text { General Government } \\
\text { Financial Balance/GDP }\end{array}$ & it "Dollarization" Ratio & $\begin{array}{l}\text { Current Acc } \\
\text { Billion) }\end{array}$ & int Balance (US\$ \\
\hline $\begin{array}{l}\text { Short term External Debt/ } \\
\text { Total External Debt }\end{array}$ & $\begin{array}{l}\text { Nominal Exports of Goods } \\
\text { and Services } \% \text { change, US } \\
\$)\end{array}$ & $\begin{array}{ll}\text { is } & \text { Government } \\
\text { S } & \text { Effectiveness }\end{array}$ & $\begin{array}{l}\text { General G } \\
\text { Balance/GD }\end{array}$ & ernment Primary \\
\hline $\begin{array}{l}\text { onetary Policy Rate }(\% \mathrm{p} \\
\text { num Dec 3I) }\end{array}$ & & & & \\
\hline
\end{tabular}

Source: Authors Calculation

Appendix-E: Table 5. Post Estimation Test

\begin{tabular}{|c|c|c|c|c|c|}
\hline \multirow[t]{5}{*}{ Brazil } & $\begin{array}{l}\text { Test of Endogeneity } \\
\text { (orthogonality conditions) }\end{array}$ & \multicolumn{3}{|c|}{ First-stage regression summary statistics } & $\begin{array}{l}\text { Test of Over Identifying } \\
\text { restriction }\end{array}$ \\
\hline & Ho: variables are exogenous & & $\mathrm{F}(8,4)$ & Prob. $>$ F & $\begin{array}{l}\text { Hansen's J chi2(7) }= \\
7.52298\end{array}$ \\
\hline & \multirow{3}{*}{$\begin{array}{l}\text { GMM C statistic } \operatorname{chi2}(\mathrm{I})= \\
2.09(\mathrm{p}=0.1083)\end{array}$} & Robust & I0.9989 & 0.0173 & $(p=0.3765)$ \\
\hline & & Instruments & R square & Adjusted & Partial \\
\hline & & & 0.9654 & 0.853 & 0.9365 \\
\hline \multirow[t]{2}{*}{ Russia } & $\begin{array}{l}\text { Test of Endogeneity } \\
\text { (orthogonality conditions) }\end{array}$ & \multicolumn{3}{|c|}{ First-stage regression summary statistics } & $\begin{array}{l}\text { Test of Over Identifying } \\
\text { restriction }\end{array}$ \\
\hline & Ho: variables are exogenous & & $\mathrm{F}(7,5)$ & Prob. $>\mathrm{F}$ & $\begin{array}{l}\text { Hansen's J chi2(6) } \\
8.23788\end{array}$ \\
\hline
\end{tabular}




\begin{tabular}{|c|c|c|c|c|c|}
\hline & \multirow{3}{*}{$\begin{array}{l}\text { GMM C statistic chi2 }(\mathrm{I})= \\
2.58195(\mathrm{p}=0.108 \mathrm{I})\end{array}$} & Robust & $4.582 \mathrm{I}$ & 0.0564 & $(p=0.2212)$ \\
\hline & & \multirow[t]{2}{*}{ Instruments } & R square & Adjusted & Partial \\
\hline & & & 0.9958 & 0.9856 & 0.76 \\
\hline \multirow[t]{5}{*}{ India } & $\begin{array}{l}\text { Test of Endogeneity } \\
\text { (orthogonality conditions) }\end{array}$ & \multicolumn{3}{|c|}{ First-stage regression summary statistics } & $\begin{array}{l}\text { Test of Over Identifying } \\
\text { Restriction }\end{array}$ \\
\hline & Ho: variables are exogenous & & $\mathrm{F}(7,5)$ & Prob.> F & $\begin{array}{l}\text { Hansen's J } \operatorname{chi2}(6)= \\
7.55405\end{array}$ \\
\hline & \multirow[t]{3}{*}{$\begin{array}{l}\text { GMM C statistic } \operatorname{chi2}(\mathrm{I})= \\
2.47297(\mathrm{p}=0.1058)\end{array}$} & Robust & 6.26192 & 0.0302 & $0.2726)$ \\
\hline & & Instruments & R square & Adjusted & Partial \\
\hline & & & 0.8949 & 0.7905 & 6.26192 \\
\hline \multirow[t]{5}{*}{ China } & $\begin{array}{l}\text { Test of Endogeneity } \\
\text { (orthogonality conditions) }\end{array}$ & \multicolumn{3}{|c|}{ First-stage regression summary statistics } & $\begin{array}{l}\text { Test of Over Identifying } \\
\text { restriction }\end{array}$ \\
\hline & Ho: variables are exogenous & & $\mathrm{F}(7,44)$ & Prob. $>\mathrm{F}$ & $\begin{array}{l}\text { Hansen's J } \operatorname{chi2}(6)= \\
5.86025\end{array}$ \\
\hline & \multirow{3}{*}{$\begin{array}{l}\text { GMM C statistic } \operatorname{chi2}(\mathrm{I})= \\
2.25272(\mathrm{p}=0.1334)\end{array}$} & Robust & $\mathrm{I} 2.8822$ & 0.0062 & $(p=0.4390)$ \\
\hline & & \multirow[t]{2}{*}{ Instruments } & R square & Adjusted & Partial \\
\hline & & & 0.9692 & 0.8952 & $0.87 \mathrm{I} 3$ \\
\hline
\end{tabular}

Source: Authors Calculation

\section{Copyrights}

Copyright for this article is retained by the author(s), with first publication rights granted to the journal. This is an open-access article distributed under the terms and conditions of the Creative Commons Attribution license (http://creativecommons.org/licenses/by/4.0/). 